\title{
CORRECTION
}

\section{Correction to: Cultural Values Underlying Psychometric Cognitive Testing}

\author{
Alfredo Ardila ${ }^{1}$ \\ Published online: 15 December 2020 \\ (c) Springer Science+Business Media, LLC, part of Springer Nature 2020
}

Correction to: Neuropsychology Review (2005) 15:185-195 https://doi.org/10.1007/s11065-005-9180-y

The html version of this article unfortunately contained a mistake in the author group. The author's name should be "Alfredo Ardila", instead of "Alfredo Ardila1".

Publisher's Note Springer Nature remains neutral with regard to jurisdictional claims in published maps and institutional affiliations.

The original article can be found online at https://doi.org/10.1007/ s11065-005-9180-y.

Alfredo Ardila

ardilaa@fiu.edu

1 Department of Communication Sciences and Disorders,

Florida International University, HLS144, Miami, FL 33199,

USA 